\title{
THE CONCEPT OF DEMOCRACY AND THE EUROPEAN CONVENTION ON HUMAN RightS
}

\author{
DR. JOSEPH ZAND*
}

\begin{abstract}
The European Convention on Human Rights, aims to guarantee civil and political rights. It is a unique international human rights instrument that provides what is widely regarded as the most effective trans-national judicial process for complaints brought by citizens and organizations against their respective governments. The aim of this Article is to contribute to the continuing debate on the notion of democracy according to the European Convention on Human Rights. Not only has the Convention been a standard-setter in Europe, but also a source of inspiration in promotion of democracy and democratic values for other regions of the world. This Article considers the elements of the Convention that directly concern democratic values. To that end, this Article critically examines the relevant Articles of the Convention on the notion of democracy, as well as the jurisprudence of the European Court of Human Rights. Furthermore, in recent decades, the Convention has made a telling contribution in relation to transitioning to peace and democracy in the former communist Eastern European states.
\end{abstract}

\section{INTRODUCTION}

The heinous atrocities committed in the course of World War II produced a flurry of aspirational and binding documents and treaties, such as the Universal Declaration of Human Rights, the Genocide Convention, the International Covenant on Civil and Political Rights (ICCPR) and International Covenant on Economic, Social and Cultural Rights (ICESCR). However, the European Convention on Human Rights (Convention) is undoubtedly the most effective human rights instrument ever devised. Since its enactment, the Convention has been a standard-setting text for transitions to peace and democracy throughout Europe. ${ }^{1}$ It is worth noting that the Council of Europe ${ }^{2}$ is no longer limited to the

* Dr. Joseph Zand, is an independent researcher, Ph.D., Ghent University, Belgium; LL.M., Leicester University, United Kingdom; LL.B., Leicester University, United Kingdom; zandjoe@hotmail.com.Faculty of Law, Inonu University, Malatya, Turkey; Joseph.zand@inonu.edu.tr.

1. Klass v. Germany, App. No: 5029/71, Eur.Ct. H.R. (ser. A-28), 59. See also, Soering v. United Kingdom, App. No: 14038/88, Eur.Ct. H.R. (ser. A-161), ๆ 88.

2. As of August 2017, the Council of Europe has 47 member states. Ten founding states (primary membership) signed the Council of Europe's Statute on 5 May 1949: Belgium, Denmark, France, Ireland, Italy, Luxembourg, the Netherlands, Norway, Sweden and the United Kingdom. Greece and Turkey are not mentioned in the Statute but those states may still be regarded as de facto founder members. http:/www.coe.int/en/web/about-us/our-member-states; see also F. BenoitRohmer, H. Klebes Council of Europe Law: Towards a Pan-European Legal Area, Council of Europe, Strasbourg 2005, p. 35.

http://doi.org/10.18060/7909.0045 
Western European states. ${ }^{3}$ Since the collapse of the Soviet Union and the end of the Cold War, the geographic and cultural influence of the Convention has progressed eastwards and now encompasses most of the former Soviet Eastern Bloc states. ${ }^{4}$ In fact, at present, 47 countries representing 800 million citizens have now recognised the right of their citizens to bring cases against them at the European Court of Human Rights (the "Court"). ${ }^{5}$ The Convention is also increasingly becoming a source of legal inspiration in other legal jurisdictions. The Convention was created as a standard-setter and upholder of liberal democracy in Europe and the issue of democracy has been one of its fundamental features. ${ }^{6}$ Therefore, the Convention was designed to maintain and promote the ideals and values of a democratic society. ${ }^{7}$

The Travaux Preparatoires - i.e. the official record - of the Convention unequivocally states that its goal was to "prevent a rebirth of totalitarianism," to

3. Under Article 3, Statute of the Council of Europe 1949, 87 UNTS 103; ETS 1, a member state "must accept the principles of the rule of law and the enjoyment by all persons within its jurisdiction of human rights and fundamental freedoms." The significance of the Convention's role in giving meaning to these obligations has been highlighted in recent years by the fact that becoming a party to the Convention is now a political obligation of membership of the Council of Europe. Parliamentary Assembly resolution 1031 (1994), On the honouring of commitments entered into by member states when joining the Council of Europe, para. 9 (14 Apr. 1994), https://perma.cc/55UA-VE4B.

4. For example, Russia ratified the Convention in May 1998 and Georgia, which only joined the Council of Europe in April 1999, ratified the Convention in June 1999. Council of Europe, Chart of signatures and ratifications of the Convention for the Protection of Human Rights and Fundamental Freedoms, (28 October 2013), https://perma.cc/7Y4W-ETBB. See generally, James A. Sweeney, Divergence and Diversity in Post-Communist European Human Rights Cases, 21 ConN. J. INT'L L. 1 (2005-2006).

5. 47 Member States, COUNCIL Of Europe, https://perma.cc/2FKZ-NGJP (last visited Oct. 28, 2013).

6. Indeed, in the preamble to the Convention, a clear link is established between the Convention and liberal democracy by stating that the maintenance and furtherance of human rights and fundamental freedoms can only be safeguarded by an effective liberal democracy and a common understanding and observance of human rights. Furthermore, the preamble goes on to assert that European countries have a common heritage of political tradition, ideals, freedom and the rule of law, which are the principles of liberal democracy and the underlying values of the Convention itself. See generally, Thomas M. Franck, The Emerging Right to Democratic Governance, 86 AMERICAN J. OF INT'L L. 46 (1992). See also, Christina M. Cerna, Universal Democracy: An International Legal Right or the Pipe Dream of the West?, 27 N.Y.U. J. INT'L L. \& Pol. 289 (1994-1995), 295; Steven Wheatley, The Democratic Legitimacy of InTERnATIONAL LAW (Hart Pub., 2010).

7. Kjeldsen, Busk Madsen and Pedersen v. Denmark, App. Nos.: 5095/71, 5920/72 and 5926/72, Eur.Ct. H.R. (ser. A-23), 27.

8. Preparatory Commission of the Council of Europe, Collected Edition of the “Travaux PréPARATOIREs” Vol. 1, 192 (Martinus Nijhoff 1975) [hearinafter Travaux I]. 
"defend our people from dictatorship," and to "strengthen the resistance in all our countries against insidious attempts to undermine our way of life." ${ }^{10}$ It goes on to stress upon the citizens of the member countries of the Council of Europe that the Convention's goal was to "define and guarantee the political basis of this association of European nations" 11 and to "ensure that member states of the Council of Europe are democratic and remain democratic" 12 as well as providing a "code of law for the democracies." 13

The Convention was a direct product of the immediate post-war effort to unify Europe. ${ }^{14}$ The Convention was a reaction to the serious human rights abuses that Europe had witnessed in the course of the Second World War. ${ }^{15}$ But, "it can also be viewed in the context of the much longer struggle to secure respect for personal autonomy, the inherent dignity of persons, and equality of all men and women."16

The preamble to the Convention asserts that European countries have a common heritage of political tradition, ideals, freedom and the rule of law, which are the principles of liberal democracy and the underlying values of the Convention itself. ${ }^{17}$ Hence, it is fair to say that the Convention was designed to maintain and promote the ideals and values of a democratic society. ${ }^{18}$ Moreover, the Convention was to achieve all this by providing a collective guarantee, if not of all applicable rights and freedoms, then at least of those considered "essential

9. Preparatory Commission of the Council of Europe, Collected Edition of the “Travaux PrÉPARAtoires” Vol. 5, 332 (Martinus Nijhoff 1975) [hearinafter Travaux V].

10. Travaux I, supra note 8 , at 8 .

11. Preparatory Commission of the Council of Europe, Collected Edition of the “Travaux PréParatoires” Vol. 2, 50 (Martinus Nijhoff 1975) [hearinafter Travaux II].

12. Id. at 60 .

13. Id. at 4 .

14. The main reason for the Convention was partly the need to elaborate on the Council of Europe's membership obligations and commitments. See generally, Convention for the Protection of Human Rights and Fundamental Freedoms and Protocol, Nov. 4, 1950, 231 U.N.T.S. 221, C.E.T.S. 5, U.K.T.S. 71 (1953) [hereinafter Convention].

15. For the framers, democracy was given a vivid significance, in contrast to the recent experience of "fascism, hitlerism, and communism". See generally, HARRIS ET. AL., LAW OF THE European Convention on Human Rights (Oxford Univ. Press, 3rd ed., 2014).

16. Ovey, C. \& White, R.C.A., European Convention on Human Rights 3 (Oxford Univ. Press, 5th ed., 2010). See also, Susan Marks, The European Convention on Human Rights and its 'Democratic Society, 'Brit. Y.B. Int'1 L., 210 (1995).

17. In the preamble to the Convention, a clear link is established between the Convention and liberal democracy by stating that the maintenance and furtherance of human rights and fundamental freedoms can only be safeguarded by an effective liberal democracy as well as a common understanding and observance of human rights. Soering v. United Kingdom, App. No: 14038/88, Eur.Ct. H.R. (ser. A-161) ๆ 88.

18. Kjeldsen, Busk Madsen and Pedersen v. Denmark, App. Nos.: 5095/71, 5920/72 and 5926/72 Eur.Ct. H.R. (ser. A-23) ๆ 53. 
for a democratic way of life." 19

Since its creation, the Court has presided over many cases dealing with democracy and its concept within the framework of the Convention, as well as the rights of anti-democratic actors in a liberal democracy. This Article will deal with relevant Articles of the Convention which encapsulate the concept of democracy through the case law of the Court and how its jurisprudence has evolved in this regard since the 1950s. In so doing, this Article will look into the Court's conception of democracy by examining what requirements are essential for a liberal democratic political system.

\section{THE NOTION OF DEMOCRACY AND THE CONVENTION}

The drafters of the Convention devoted a prominent role to promotion of pluralism and democracy in Western European states by incorporating the idea of democracy as a cornerstone to protect the rights of the individual. ${ }^{20}$ The notion of a "democratic society" permeates the entire European Convention system. In the preamble to the 1949 statute of the Council of Europe, the participating states reaffirm "their devotion to the spiritual and moral values which are common heritage of their peoples and the true source of individual freedom, political liberty and the rule of law, principles which form the basis of all genuine democracy." ${ }^{\prime 21}$ The Strasbourg organs have emphasised the point that "democracy does not simply mean that the views of the majority must always prevail[;]" but, "a balance must be achieved which ensures fair and proper treatment of minorities and avoid abuse of a dominant position." ${ }^{22}$

In recent decades, the Court has turned its attention to the fundamental link between the substantive rights guaranteed by the Convention and the concept and existence of democracy within the member states. ${ }^{23}$ There is no doubt that the Court considers qualities such as pluralism, tolerance, broadmindedness, equality, liberty and encouraging self-fulfilment as important characteristics of any functioning democracy. ${ }^{24} \mathrm{On}$ the question of the relationship between democracy

19. Travaux I, supra note 8 , at $43-44$.

20. The current mandate of the Council of Europe was established at a summit, which took place in Warsaw in 2005. See generally, Council of Europe, Warsaw Declaration (Oct. 18, 2013), https://perma.cc/Z9P2-FFP7. See also, Human \& Constitutional Rights, Bowman v. United Kingdom (1998), https://perma.cc/3RVY-FCT9.

21. Statute of the Council of Europe, European Treaty Series No. 001 (1949); The European Convention CONV 850/03, draft treaty for establishing a constitution for Europe (2003); see also LAWRENCE PRATCHETT, DEVELOPING DEMOCRACY IN EUROPE: AN ANALYTICAL SUMMARY OF THE COUNCIL OF EUROPE'S ACQUIS, COUNCIL OF EUROPE (09 FEB. 20050, p. 30.

22. Sorensen v. Denmark and Rasmussen v. Denmark, 46 Eur. H.R. Rep. 752, ๆ 58 (2008). See also, Young v. UK, Eur. Ct. H.R. (ser. A-44) ๆ 63 (1983).

23. James A. Sweeney, The European Court of Human Rights in the Post-Cold War ERA: UNIVERSALITY IN TRANSITION 19 (Routledge, 2012).

24. Oberschlik v. Austria, No. 11662/85, Series A, No. 204, 23.5.91, ๆ 58; See also, Ovey, 
and the Convention, the Grand Chamber in its unanimous decision in the case of the United Communist Party of Turkey v. Turkey held:

That is apparent, firstly, from the preamble to the Convention, which establishes a very clear connection between the Convention and democracy by stating that the maintenance and further realisation of human rights and fundamental freedoms are best ensured on the one hand by an effective political democracy and on the other by a common understanding and observance of human rights. ${ }^{25}$

Moreover, in its Grand Chamber decision in Gorzelik and others v. Poland, the European Court of Human Rights (ECtHR), defined pluralism as "the genuine recognition of, and respect for, diversity and dynamics of cultural conditions, ethnic and cultural identities, religious beliefs, artistic, literary and socioeconomic ideas and concepts. ${ }^{26}$

\section{DEMOCRATIC RIGHTS AND THE CONVENTION}

The centrality of democracy to the Convention system does not mean that the precise form of democracy recommended by the Convention is particularly clear. ${ }^{27}$ Nonetheless, the Court has consistently maintained that at the heart of the notion of democracy is the full participation of all the citizens of the High Contracting Parties. ${ }^{28}$ Participatory democracy includes the formal conception of majority rule, which concerns the method of decision-making and, over and above this requirement, also demands that the majority respect the equal worth of all citizens. ${ }^{29}$ Therefore, democracy is the only political model that the Convention aims for and finds compatible with it. ${ }^{30}$ In a democracy, however, it is assumed that limitations on individual rights and freedoms for the common good or to protect more compelling rights of others would be justified. ${ }^{31}$

As a democracy is based on the equal worth of individuals, at least certain human rights must be protected. In particular, political rights, such as freedom of expression, the right to vote, and the freedom of assembly, are understood as vital

supra note 16, at 326; J.G. Merrills, The Development of International LAW By the European Court of Human Rights CHP 6 (Manchester Univ. Press, 1993).

25. The United Communist Party of Turkey v. Turkey, 26 Eur. H.R. Rep. 121 (1998).

26. Gorzelik v. Poland, App. 44158/98, Eur. Ct. H.R. 92, ๆ 92 (2004).

27. SwEENEY, supra note 23, at 148.

28. Hirst v. United Kingdom (GC), App No. 74025/01, ECHR 2005-IX, 6 October 2005, at 62.

29. G. Lautenbach, The Concept of the Rule of LaW and the European Court of Human Rights 65 (Oxford Univ. Press, 2013).

30. R.O. O'Connell, Towards a Stronger Concept of Democracy in the Strasbourg Convention, Eur. Hum. RTs. L. Rev. 281 (2006).

31. See generally, Rosalyn Higgins, Derogations under Human Rights Treaties, Brit. Y.B. Int'1 L. 48 (1978); Marks, supra note 16, at 212. 
for a functioning democracy. ${ }^{32}$ Democracy must also be understood to require the protection of other human rights, such as the right to family life and correspondence and the right to religion. Therefore, according to the Court, Articles 8, 9, 10 and 11 of the Convention encapsulate the concept of democracy and have common features which may require interference with the use of the rights set out by these Articles. ${ }^{33}$ These interferences must be evaluated by the benchmark of what is "necessary in a democratic society." ${ }^{34}$ The only type of necessity to justify an interference with any of those rights is one which may claim to derived from the ideals of a "democratic society." ${ }^{35}$ If a restriction on democracy is prescribed by law, the Court then would consider whether the law, or rather the way in which it was applied, is "necessary in a democratic society" for any of the reasons outlined in the aforementioned Articles. ${ }^{36}$ Hence, the Court has developed the approach that states have a "margin of appreciation" in deciding whether a particular restriction on a right is required in the given circumstance. ${ }^{37}$ In the case of Handyside v. United Kingdom, the Court stated:

By reason of their direct and continuous contact with the vital forces of their countries, state authorities are in principle in a better position than the international judge to give an opinion on the exact content of these requirement as well as on the 'necessity' of a 'restriction' or 'penalty' to meet them. ${ }^{38}$

The Court also goes on to say:

Whilst the adjective 'necessary' ...is not synonymous with "indispensable", neither has it the flexibility of such expressions as "admissible", "ordinary", "useful", "reasonable" or "desirable".

32. Yumak and Sadak v. Turkey, App. No. 10226/03, 30 January 2007, at 65.

33. Zdanoka v. Latvia, App. No. 58278/00 Eur. Ct. H.R. ๆ 115 (2006). See also, Gerhard van der Schyff, The Concept of Democracy as an Element of the European Convention, 38 THE CoMP. AND INT'L L. J. OF SOUTHERn AFR. 355 (2005).

34. C. Gearty, Democracy and Human Rights in the European Court of Human Rights: A Critical Appraisal, 51 N. IR. LEGAL Q. 381, 388 (2000).

35. G.H. Fox, Democratic Governance and International Law 93 (Cambridge Univ. Press 2000).

36. I. Loveland, Constitutional Law, Administrative Law, and Human Rights: A CRitical InTROdUCtion 593 (Oxford Univ. Press, 6th ed., 2012).

37. The term 'margin of appreciation has been used for some time to refer to the room for manoeuvre that the Strasbourg institutions are prepared to accord national authorities in fulfilling some of their principle obligations un the European convention on Human Rights. See generally, Yutaka Arai-Takahashi, The Margin of Appreciation Doctrine and the Principle of Proportionality in the Jurisprudence of the ECHR (Interesentia Publishers, 2002); Onder Bakircioglu, The Application of the Margin of Appreciation Doctrine in Freedom of Expression and Public Morality Cases, 8 German L.J. 711 (2007).

38. Handyside v. United Kingdom, Eur. Ct. H.R. (ser. A-24) (1976); 1 Eur. H.R. Rep. 737, 48 (1979-1980). 
Nevertheless, it is for the national authorities to make the initial assessment of the reality of the pressing social need implied by the notion of "necessary in this context." 39

\section{THE NOTION OF DEMOCRACY AND RELEVANT ARTICLES OF THE CONVENTION}

As discussed briefly above, through its case law, the Court has identified certain provisions of the Convention which clearly encapsulate the concept of a democratic society. ${ }^{40}$ On this point, it has been noted that "in relation to the Convention proper, the Court's conception of democracy is only elucidated incidentally--through consideration of the democratic rights contained in the Convention." ${ }^{41}$ The substantive rights that are considered to comprise the concept of democracy are easily identified. ${ }^{42}$ Express reference to the concept of democracy may be seen in the second paragraphs of Articles 8-11 of the Convention, as well as Article 2(3)-(4) of the Fourth Protocol. ${ }^{43}$

Articles 8-11 set out a Convention right in the first paragraph and possible qualifications to the right in their second paragraph as a means of right-restrictive measures. ${ }^{44}$ Despite some

"differences of detail in the nature of the limitations arising under each article, there is sufficient commonality of approach to justify a collective consideration of these limitations before examining the substantive rights protected under each of these articles." ${ }^{\prime 5}$

The Court has explicated that "there is undoubtedly a link between all of these provisions, namely the need to guarantee respect for pluralism of opinion in a democratic society through the exercise of civic and political freedoms." ${ }^{46}$

Initially, with regard to the concept of democracy, the Court considered Article 10 protecting "freedom of expression" and Article 11 protecting "freedom of assembly and association" as the more relevant articles to the concept of democracy and the democratic process. ${ }^{47}$ This transpires through the preceding

39. Id.

40. Austria v. Italy, 4 Y.B. Eur. Conv. on H.R. 116, 138 (1961).

41. Paul Harvey, Militant democracy and the European Convention on Human Rights, 29 EUROPEAN L. REV. 3, 407, 412 (2003).

42. SWEENEY, supra note 23, at 151.

43. See generally D.J. Harris et. al., Law of the European Convention on Human Rights ( $2^{\text {nd }}$ ed. 2009), especially Chapter 8 Articles 8-11: General Considerations, pp. 341-360.

44. Al-Nashif v. Bulgaria, App. No. 50963/99, _ Eur. Ct. H.R.__ (2002).

45. Robin C.A. Wright \& Claire Ovey, The European Convention on Human Rights $\left(5^{\text {th }}\right.$ ed. 2010), 308; see also Steven Greer, "The Exceptions to Articles 8 to 11 of the European Convention on Human Rights," (Council of Europe Pub., Strasbourg, 1997).

46. Zdanoka v. Latvia, no. 58278/00 _ Eur. Ct. H.R._』 115 (2006).

47. Handyside v. United Kingdom, 24 Eur. Ct. H.R. (ser. A) 94 (1976); Lingens v. Austria, 
judgments of the Court on Articles 10 and 11 respectively, as well as on merits of applications and ultimately through Article 17 which sets out "restrictions on activities subversive of Convention rights," in decisions on admissibility. Also relevant is the rather weaker protection offered by Article 3 of Additional Protocol No.1 (hereinafter Article 3 of Protocol No. 1), which obligates member states to hold free elections, which according to the Court "enshrines a characteristic of an effective political democracy." ${ }^{48}$

Moreover, Article 17 of the Convention sets out prohibitions from abuses of the Convention rights by stating that "nothing in this Convention may be interpreted as implying for any state, group or person any right to engage in any activity or perform any act aimed at the destruction of any of the rights and freedoms set forth herein or at their limitation to a greater extent than is provided for in the Convention." 49

Therefore, Article 17 prevents member states from abusing their Convention rights in order to curtail the rights and freedoms of others. This provides a safety mechanism specifically designed to prohibit totalitarian movements from using human rights as a means of furthering their cause. ${ }^{50}$

Nonetheless, it has been noticed elsewhere that freedom of expression under Article 10 and Article 3 of Protocol No. 1, which provides for the guarantee of free elections held at reasonable intervals, are the two provisions of the Convention, which in the opinion of the Court, "embodied the characteristics of a democratic society." 51 The Court has stressed that the eminence of "freedom of expression constitutes one of the essential foundations of a democratic society and one of the basic conditions for its progress and for each individual's selffulfilment." 52 In recent decades, Article 8 , which protects "private and family life, home, and correspondence," ${ }^{53}$ and Article 9, which protects "freedom of religion and belief," have also been considered by the Court in relation to the general

103 Eur. Ct. H.R. (ser. A) ๆ 41 (1986); Oberschlik v. Austria, 204 Eur. Ct. H.R. (ser. A) ๆ 58 (1991).

48. Mathieu-Mohin v. Belgium, 2 March 1987, Series A No. 113, (1988)10 EHRR 1, ๆ 47; and Matthews v. United Kingdom, App. No. 24833/94, 18 February 199928 EHRR, 361, ECHR 1999-I, ๆ 42.

49. Article 17 of European Convention on Human Rights; see also HARRIS ET AL., supra note 15 , at $648-652$.

50. See Vona v. Hungary, App. No. 35943/10, _Eur. Ct. H.R.__ I 34 (2013) (“" [T] he Court had observed that 'the general purpose of Article 17 is to prevent totalitarian groups from exploiting in their own interests the principles enunciated by the Convention."); see also Communist Party (KPD) v. Germany, App. No. 250/57, 1 Y.B. Eur. Conv. on H.R. 222, 19 86-89 (1957).

51. A. Mowbray, "The Role of the European Court of Human Rights in the Promotion of Democracy," Public Law 703, 704 (1999).

52. Delfi AS v. Estonia, App. No. 64569/09__Eur. Ct. H.R._ at 50 (2003).

53. The Court has considered this article particularly in relation to the issue of personal correspondence. See Halford v. United Kingdom, 24 Eur. Ct. H.R. 523 (1997); Leander v. Sweden, 9 Eur. Ct. H.R., at 433 (1987). 

EUROPEAN CONVENTION ON HUMAN RIGHTS

concept of democracy. ${ }^{54}$

\subsection{ARTICLE 8: RIGHT TO RESPECT FOR PRIVATE AND FAMILY LIFE}

Article 8 of the Convention protects four connected rights: ${ }^{55}$ the right to private life, the right to family life, the right to respect for home, and the right to respect for correspondence. ${ }^{56}$ Each one of these rights is "autonomous," and the Court is not constrained by any national interpretation..$^{57}$ The Court consistently has refrained from providing a comprehensive definition of private life. ${ }^{58}$ Article 12 of the Convention complements Article 8, guaranteeing the right to marry and found a family. ${ }^{59}$ In addition, the member states of the Council of Europe have determined to reinforce the equality of spouses in family life and to that end have adopted Article 5 of the Seventh Protocol. ${ }^{60}$

Article 8 places the obligation on states to respect a wide range of personal interests. ${ }^{61}$ Article 8 secures not only negative but also positive aspects of the rights in question. ${ }^{62}$ The Court has spelled out the dual nature of Article 8 rights:

54. Malcolm D. Evans, Religious liberty AND International LAW IN Europe (Cambridge U.P., 2008) at 282-84.

55. According to Article 8 of the Convention:

1. Everyone has the right to respect for his private and family life, his home and his correspondence.

2. There shall be no interference by a public authority with the exercise of this right except such as is in accordance with the law and is necessary in a democratic society in the interests of national security, public safety or the economic well-being of the country, for the prevention of disorder or crime, for the protection of health or morals, or for the protection of the rights and freedoms of others.

56. See generally, Ivana Roagna, "Protecting the right to respect for private and family life under the European Convention on Human Rights," Council of Europe Human Rights Handbooks (2012).

57. Harris et al., supra note 43 , at 361 .

58. Niemietz v. Germany, App. No. 13710/88, _Eur. Ct. H.R._ \ 29 (1992).

59. Article 12 of the Convention states: "Men and women of marriageable age have the right to marry and to found a family, according to the national laws governing the exercise of this right." See Schalk v. Austria, App. No. 30141/04, _Eur. Ct. H.R._ I 49 (2010).

60. Article 5 of the Seventh Protocol reads as follows: "Spouses shall enjoy equality of rights and responsibilities of a private law character between then, and in their relations with their children, as to marriage, during marriage, and in the event of its dissolution. This article shall not prevent states from taking such measures as are necessary in the interest of the children." See also Parliamentary Assembly of the Council of Europe, Recommendation 1271 (1995) 'on discrimination between men and women in the choice of a surname and in the passing on of parents surnames to children.' Assembly debate on 28 April 1995 (16th Sitting) (see Doc. 7259, report of the Committee on Legal Affairs and Human Rights, rapporteurs: Mrs Err and Mr Masson).

61. Harris et al., supra note 43.

62. Marckx v. Belgium, 2 Eur. Ct. H.R. 330, 342 (1979). 
[A]lthough the object of Article 8 is essentially that of protecting the individual against arbitrary interference by the public authorities, it may involve the authorities' adopting measures designed to secure respect for private life and home even in the sphere of the relations of individuals between themselves. ${ }^{63}$

On one hand, the state in question is obliged not to interfere with the domain of private and family life, home, or correspondence. On the other, it is required to take particular measures necessary to realise the effective enjoyment of these rights.

\subsubsection{ARTICle 8 AND PERSONAL CORRESPONDENCE}

When the Court finds a particular measure to be in "interference" with the rights embodied under the first paragraph of Article 8, it must consider whether such interference may be justified by the conditions laid down in the second paragraph.$^{64}$ The standard formula developed in the case law is common to other personal freedoms set out in Articles 9 through 11. A violation of Article 8 can only be justified if it is "in accordance with the law," has a "legitimate aim," and is "necessary in a democratic society."

The issue of interference with correspondence by national authorities has presented a new challenge to the Court in recent decades. Correspondence includes postal correspondence, telephone calls, emails, and text messages. ${ }^{66}$ According to the Court, opening, reading, censoring, or deleting correspondence violates Article 8 of the Convention. The controversial issues of surveillance of communication $^{67}$ and prisoners' right to correspondence ${ }^{68}$ have recently been under sharp scrutiny. ${ }^{69}$

Therefore, in order to curb member states' discretionary powers, the Strasbourg organs require that the law in question be accessible and foreseeable. ${ }^{70}$ In particular, the "foreseeability test" provides a crucial safeguard for the citizen, requiring the law to be "sufficiently clear" and precise to give "adequate indication" of the circumstances and conditions that secret surveillance or

63. Dees v. Hungary, App. No. 2345/06, _ Eur. Ct. H.R._ \ 21 (2010); see also Airey v. Ireland, App. No. 6289/73 _ Eur. Ct. H.R. _ (1979); X and Y v. Netherlands, 6 Eur. Ct. H.R. CD 311,313 (1985).

64. OvEY, supra note 16 , at 310-12.

65. Harris et al., supra note 43 at 344.

66. See Malone v. United Kingdom, App. No. 8691/79,7 Eur. Ct. H.R. 14 (1985) (interception of telephone calls); Halford v. United Kingdom, supra note 53 (interception of email); Golder v. United Kingdom, App. No. 4451/70, _Eur. Ct. H.R. _ (1975) (interception of post).

67. Kennedy v. United Kingdom, App. No. 26839/05, _ Eur. Ct. H.R. _ (2010).

68. See Klamecki v. Poland (no. 2), App. No. 31583/96,_ Eur. Ct. H.R. _ I 144 (2003); Kucera v. Slovakia, App. No. 48666/99, _ Eur. Ct. H.R._』 127 (2010).

69. See A. Mowbray, European Convention on Human Rights, 561-589 (3 ${ }^{\text {rd }}$ ed. 2012).

70. Sunday Times v. United Kingdom, App. No. 6538/74,2 Eur. Ct. H.R. 245 ๆ 56 (1979). 

EUROPEAN CONVENTION ON HUMAN RIGHTS

interceptive measures may be employed. ${ }^{71}$ Another implication of the "foreseeability test" is the requirement that authorities provide an adequate safeguard against possible abuses, which clearly demonstrates the extent of the authorities' discretion and defines the circumstances in which it is to be exercised. $^{72}$ In other areas of complaints under Article 8, by contrast, the first standard has rarely been contested, and the Convention bodies have focused their examination on the third standard: "necessary in a democratic society."

The best example of the Court exercising this judicial oversight is when it presided over a series of cases involving British citizens alleging illegal interception of their correspondence. ${ }^{74}$ The Court held that because there was no domestic law to regulate such activities, a breach of Article 8 by the United Kingdom occurred. ${ }^{75}$ These rulings prompted the British government to fill this lacuna by enacting the Regulation of Investigatory Powers Act $2000 .^{76}$ As a consequence of this Act, telephone-tapping civil cases in the United Kingdom are now brought under Article 8 of the Convention. ${ }^{77}$ In the most recent case, a number of British politicians and celebrities filed a claim against the Metropolitan Police. ${ }^{78}$ The politicians and celebrities successfully argued that there was a breach of Article 8 since the police had failed to inform them about the telephone hacking and had failed in their duty to carry out a thorough investigation as part of their positive duty under Article $8 .^{79}$

Moreover, it is worth noting that the doctrine of margin of appreciation plays a pivotal role in the development of Article 8 case law, providing states a certain degree of discretion, particularly where the Court is reluctant to impede on the decisions made by states in relation to issues, i.e. "where a different approach is justified by local conditions." ${ }^{\prime 0}$ Nonetheless, as the concept of the "margin of

71. Kennedy v. United Kingdom, supra note 67, at 9 119-20; see also Klass and Others v. Germany, App. No. 5029/71, _ Eur. Ct. H.R._ \33(1978).

72. Michaud v. France, App. No. 12323/11_Eur. Ct. H.R. _ I 88 (2012).

73. Ian Cameron, National Security and the European Convention on Human Rights, Kluwer Law, The Hague, 2000, at 36.

74. See Malone v. United Kingdom, supra note 66 (interception of telephone calls); see also Halford v. United Kingdom, supra note 53 (interception of email).

75. See Copland v. United Kingdom, App. No. 62617/00, _ Eur. Ct. H.R. _ \甲 41-42 (2001).

76. Regulation of Investigatory Powers Act 2000 PARLIAMENT OF THE UNITED KINGDOM (July 28, 2000), http://www.legislation.gov.uk/ukpga/2000/23/introduction[https://perma.cc/A3UTVHAW].

77. Kennedy v. United Kingdom, supra note 67, at 9118.

78. Phone hacking: Met police failed to warn victims, BBC, Feb. 7, 2012, http://www.bbc.co.uk/news/uk-16922305[https://perma.cc/V7QM-M9VS].

79. $\mathrm{R}$ (on the application of Bryant and others) v. Commissioner of the Police of the Metropolis EWHC 1314 (2011) (Admin). In February 2012, the Metropolitan Police admitted it had acted unlawfully, and the case was settled out of court.

80. Harris et al., supra note 43, at 363. 
appreciation" has evolved in the case law of the Court, it has shown willingness to vary the margin according to the circumstances, subject matter, and background to the issue before the Court, while retaining some control over state conduct. ${ }^{81}$

\subsection{ARTICLE 9: FREEDOM OF THOUGHT, CONSCIENCE AND RELIGION}

Article 9 of the Convention protects the rights to freedom of thought, conscience and religion. ${ }^{82}$ In recent years, academic discussion of religious freedom in Europe and its relation to the concept of democracy has centered on the jurisprudence of the European Court of Human Rights under Article 9 of the Convention. ${ }^{83}$ Article 14 (prohibition of discrimination) of the Convention is also relevant to this conversation. ${ }^{84}$ On this point, the Court has reiterated that Article 9 is not simply "one of the most vital elements that go to make up the identity of believer" but also "a precious asset for atheists, sceptics, and the unconcerned." The rights to freedom of thought, conscience and religion are unqualified. ${ }^{86}$ This includes the right to hold a religion or belief and to change it. ${ }^{87}$ For the Article to apply, a belief must "attain a certain a level of cogency, seriousness, cohesion, and importance," and more importantly, abide by the possible qualifications in Article 9(2) ${ }^{88}$ This provision allows the state to interfere with the right freedom of thought, conscience and religion if the three tests in Article 9(2) are met. ${ }^{89}$ The interference must be "prescribed by law," have one of the legitimate aims listed in Article 9(2), and be "necessary in a democratic society." 90

Despite the importance and the extent of interests protected by Article 9,

81. Valentino Acatrinei v. Romania, App. No. 18540/04, _ Eur. Ct. H.R. _ \ 58 (2013); OvEY, supra note 16 , at 81

82. According to Article 9 of the European Convention on Human Rights protects the right to freedom of thought, conscience and religion:

Everyone has the right to freedom of thought, conscience and religion; this right includes freedom to change his religion or belief and freedom, either alone or in a community with others and in public or private, to manifest his religion or belief in worship, teaching, practice and observance.

Freedom to manifest one's religion or beliefs shall be subject only to such limitations as are prescribed by law and are necessary in a democratic society in the interests of public safety, for the protection of public order, health or morals, or for the protection of the rights and freedom of others.

83. N. Doe, Law and Religion in Europe, OXFORD U.P., 2011, at 40.

84. S. Knight, Freedom of Religion, Minorities, and the Law, OXFOrD U.P., 2007, at 56.

85. Buscarini v. San Marino, App. No. 24645/94, Eur. Ct. H.R., đ 34 (1999).

86. R. Sandberg, Law and Religion, CAMBRIDGE U.P., 2011, at 82.

87. Id.

88. Campbell and Cosans v. United Kingdom, App. Nos. 7511/76 and 7743/76, 4 Eur. H.R. Rep. 293 (ser. A) No. 48, ๆ 36 (1982).

89. Sandberg, supra note 86 , at 82.

90. Id. 
relatively few claims alleging violations of Article 9 have been made and only a small proportion of those have given rise to successful claims due, according to some observers, to the traditionally cautious approach taken by the Courts and the Commission in the early days of the Convention..$^{91}$ As a result, the case law related to this right is very recent with the first successful claim of a violation of this article delivered in 1993 in the much referred to Kokiknakis v. Greece case. ${ }^{92}$ Since then, however, a rich and often controversial jurisprudence has begun to develop, including two judgments on Turkish attempts to ban the wearing of Muslim headscarves in certain higher education establishments, ${ }^{93}$ the fallout from the publication of cartoons of the Prophet Muhammad in Denmark in 2005, ${ }^{94}$ and the Grand Chamber's reversal of the judgment backing a challenge to the display of the Christian crucifix in Italian state schools. ${ }^{95}$ Likewise, the Court's allowing Switzerland a margin of appreciation for banning of the construction of new minarets by virtue of a constitutional amendment in 2009 has aroused some thought-provoking legal arguments. ${ }^{96}$

\subsubsection{DEMOCRACY AS A LIMIT ON RESTRICTING FREEDOM OF RELIGION}

To justify a restriction on religion or a belief and the extent to which it is "necessary in a democratic society" has often been a controversial issue. ${ }^{97}$ In line with other international human rights instruments on religious liberty, Article 9 enshrines the rights in their first paragraph, and provides for the possible qualifications to their right in their second paragraph. The qualifications of Article 9 are slightly different than other personal freedoms since they pertain only to the manifestation of religion or belief (the forum externum), rather than the act or state of believing itself (the forum internum) ${ }^{98}$ Interpreting the scope

91. Harris et al., supra note 43, at 425.

92. Kokiknakis v. Greece, App. No. 14307/88, 17 Eur. H.R. Rep. 379 (May 25, 1993). On the Kokkinakis case, see Evans, supra note 54, at 282-84, 332-35.

93. Leyla Şahin v. Turkey (GC) App. No. 30814/06, Eur. Ct. H.R. (, 2011). See also K. Altıparmak \& O. Karahanoğulları, After Şahin: The Debate on Headscarves is Not Over, 2 European Constitutional L. Rev. 268 (2006); D. McGoldrick, Human Rights and Religion: The Islamic Headscarf Debate in Europe, Oxford: Hart (2006).

94. Special Report: The Muhammad Cartoon Row, BBC, Feb. 7, 2006, http://news.bbc.co.uk/2/hi/in_depth/4677976.stm[https://perma.cc/BLP7-FYFN].

95. Lautsi v. Italy (GC) App. No. 30814/06, Eur. Ct. H.R. (2011).

96. On 29 November 2009 , the majority of Swiss (57 per cent) and the majority of cantons in a referendum approved the popular initiative "against the construction of minarets" and in this way introduced a ban on the construction of further minarets into the federal Constitution (Article 72 para. 3). The Court rejected the applications, as the applicants could not demonstrate a direct effect on their beliefs. Quardiri v Switzerland, App. No. 65840/09, 28 June 2011; Ligue des Musulmans de Suisse v Switzerland, App. No. 66274/09, 28 June 2011.

97. Harris et al., supra note 43, at 437.

98. ANDREW HAMBER, RELIGIOUS EXPRESSION IN THE WORKPlACE AND THE CONTESTED 
of Article 9(1) has been rather challenging, and the European Commission's decision in Arrowsmith v. United Kingdom holding that not all actions motivated by religious belief fall within it, has been met with some criticism. ${ }^{99}$

In applying the limitations contained in Article 9(2), the Court has been rather sensitive to the varied constitutional traditions of the member states of the Council of Europe, notwithstanding the fact that this approach has been criticised by certain scholars at times. ${ }^{100}$ The main characteristic of Article 9 in relation to this study is the extent to which the Court has recognised a strong link between freedom of religion and a democratic society. According to the Court, "freedom of thought, conscience and religion is one of the foundations of a democratic society within the meaning of the Convention." ${ }^{01}$ In this manner, Article 9 needs to be interpreted in light of other Convention rights, such as Article 11, the right of freedom of assembly and association. ${ }^{102}$ Consequently, interference with the rights stipulated in Article 9 may be examined not only as an infringement on the applicant's own religion or beliefs, but also as an indirect violation on the democratic fabric of society. ${ }^{103}$

In order to justify a restriction on Article 9, it must comply with the conditions specified in Article 9(2), which must be prescribed by law and be necessary in a democratic society in the interest of public safety, for the protection of public order, health or morals, or for the protection of the rights and freedoms of others. ${ }^{104}$ These specific "interests" are more commonly referred to in the European jurisprudence as "legitimate aims." ${ }^{105}$ It is also important to note that other major international human rights instruments adopt the same approach to the issue of religious belief by striking a balance between the "legitimacy" of restrictions and their "necessity" to limiting freedom of religion. ${ }^{106}$

ROLE OF LAW 12 (Routledge, 2016).

99. Evans supra note 54, at 115.

100. Id.

101. Hasan and Chaush v. Bulgaria, App. No. 30985/96, Eur. Ct. H.R., ๆ 60 (2000). See also Serif v. Greece, 31 Eur. H.R. Rep. 20 (2001).

102. Id. at 962 .

103. James A. Sweeney, Freedom of Religion and Democratic Transition, TrAnsitionaL JurisprudenCE AND THE ECHR: Justice, Politics AND Rights at 105 (A. Buyse \& Hamilton, M. eds., Cambridge U.P. 2011).

104. Id.

105. Id.

106. Freedom of religion is protected in all other major international and regional human rights instruments, including Article 18 of the Universal Declaration of Human Rights (UDHR), Article 18 of the International Covenant on Civil and Political Rights (ICCPR), Article 3 of the American Declaration of the Rights and Duties of Man (American Declaration), Article 12 of the American Convention on Human Rights (ACHR) and Article 8 of the African Charter on Human People's Rights (ACHRP). 


\subsection{ARTICLE 10: FREEDOM OF EXPRESSION}

Freedom of expression, in line with various constitutional and international law instruments, is enshrined in Article 10 of the Convention. ${ }^{107}$ The Court has consistently underlined the importance of the right to freedom of expression throughout its case law. It has described Article 10 as one of the cardinal rights guaranteed under the Convention and the very essential foundation of a democratic society. ${ }^{108}$ This provision comprises freedom of expression, freedom of information, freedom of communication via mass media, and specific parts of freedom of artistic and academic expression. ${ }^{109}$ Indeed, the marked importance of these rights and the demand for its special protection due to its close linkage to democracy's political process is an indispensable part of the Convention. ${ }^{110}$ The Court has consistently maintained that states are under the obligation to ensure that private individuals can effectively exercise their right of communication between themselves. ${ }^{111}$ Furthermore, freedom of political debate is at the very core of the concept of a democratic society which prevails throughout the Convention. ${ }^{12}$ The Court has repeatedly reiterated that "freedom of expression constitutes as one of the essential foundations of democratic society, one of the basic conditions for its progress and for each individual's selffulfilment."113 The Convention has underlined the need for transparency and accountability on the part of the high contracting states. ${ }^{114}$ In ascertaining whether

107. According to Article 10 of the Convention:

1. Everyone has the right to freedom of expression. This right shall include freedom to hold opinions and to receive and impart information and ideas without interference by public authority and regardless of frontiers. This Article shall not prevent states from requiring the licensing of broadcasting, television or cinema enterprises.

2. The exercise of these freedoms, since it carries with it duties and responsibilities, may be subject to such formalities, conditions, restrictions or penalties as are prescribed by law and are necessary in a democratic society, in the interests of national security, territorial integrity or public safety, for the prevention of disorder or crime, for the protection of health or morals, for the protection of the reputation or rights of others, for preventing the disclosure of information received in confidence, or for maintaining the authority and impartiality of the judiciary.

108. See generally M. Macovei, Freedom of Expression: A to Implementation of Article 10 of the European Convention on Human Rights, HuMAN Rights HANDBOOKS No. 2 ( $2^{\text {nd }}$ ed. 2004).

109. C.Grabenwarter, European CONVEntion On Human Rights:COMmentary, at 252 (Beck/Hart Pub. ed. 2014).

110. Harris et al., supra note 43, at 443.

111. Hertel v. Switzerland, 28 Eur. H.R. Dec. \& Rep. , 46 (1998). See also Steel and Morris v. United Kingdom, App. No. 68416/01, Eur. Ct. H.R., 87 (2005), Animal Defenders International v. United Kingdom [GC], App. No. 48876/08, Eur. Ct. H.R., ๆ 100 (2013).

112. Lingens v. Austria, Eur. Ct. H.R. (ser. A) No. 103, 41 (1986).

113. Thoma v. Luxemburg, App. No. 38432/97, Eur. Ct. H.R. (2001).

114. OOO Ivpress v. Russia, App. Nos. 33501/04, 38608/04, 35258/05 and 35618/05, Eur. 
a positive obligation to act exists in a particular situation, "regard must be had to the fair balance that has to be struck between the general interest of the community and interests of individuals." 115

The most protected class of expression has been political expression because the Court considers such expression to be an essential part of any effective pluralist democracy that ensures respect for fundamental human rights. ${ }^{116}$ The Court has emphasized this point forcefully, stating: "[I]n a democratic system, the acts or omissions of the government must be subject to the close scrutiny not only the legislative and judicial authorities, but also the press and public opinion."117 This point was reiterated in the United Communist Party of Turkey case, in which the Court considered pluralism at the heart of its conception of democracy. ${ }^{118}$ Hence, the Court firmly puts the onus on the member states as the "ultimate guarantors of the principle of pluralism," especially in the context of media. ${ }^{119}$ As the Court famously held in Handyside v. United Kingdom, even opinions which "shock, offend, or disturb" should be tolerated. ${ }^{120}$ In line with this, the Court in the case of Vajnai v. Hungary reiterated that:

A legal system which applies restrictions on human rights in order to satisfy the dictates of public feelings - real or imaginary - cannot be regarded as meeting the pressing social needs recognised in democratic society, since the society must remain reasonable in its judgment. To hold otherwise would mean that freedom of speech and opinion is subjected to the heckler's veto. ${ }^{121}$

In the recent case of Cumhuriyet Vakfi and Others v. Turkey, the Court reiterated the importance of freedom of expression as "one of the essential foundations of a democratic society and one of the basic conditions for its progress and for each individual self-fulfilment." 122

Ct. H.R., ๆ 55 (2013). See also Eur. Consult. Ass., Comm. Of Ministers, "Declaration on freedom of political debate in the Media" (adopted Feb 12, 2004 at the $872^{\text {nd }}$ Meeting of the Ministers' Deputies), (Oct. 28, 2013) https://wcd.coe.int/ViewDoc.jsp?id=118995[https://perma.cc/Q8YGPU9B].

115. Ozgur Gundem v. Turkey, App. No. 23144/93, Eur. Ct. H.R., ๆ 43 (2000).

116. Mowbray, supra note 69 , at 626 .

117. The interest that the public may have in particular information can sometimes be so strong as to override even a legally imposed duty of confidence. Guja v. Moldova, App. No. 14277/04, Eur. Ct. H.R. (2008). See also Fressoz and Roire v. France [GC], App. No. 29183/95, Eur. Ct. H.R. (1999); Radio Twist, a.s. v. Slovakia, App. No. 62202/00, Eur. Ct. H.R. (2006).

118. United Communist Party of Turkey, op. cit, $₫ 43$.

119. Manole v. Moldova, App. No. 13936/02, Eur. Ct. H.R., ๆ 107 (2009).

120. Handyside v. United Kingdom, App. No. 5493/72, Eur. Ct. H.R., ๆ 49 (1976).

121. Vajnai v. Hungary, App. No. 33629, Eur. Ct. H.R., $\mid 57$ (2008).

122. Cumhuriyet Vakfi v. Turkey, App. No. 28255/07, Eur. Ct. H.R., 156 (2013). 


\subsubsection{FREEDOM OF EXPRESSION AND TRANSITION TO DEMOCRACY}

In recent decades, both the Court and the Commission have acknowledged that in a transition to democracy, it may be legitimate to curtail forms of speech which are very critical of the state. ${ }^{123}$ As Judge Carrillo Salcedo in the case of Castells v. Spain observed:

In a situation where politically motivated violence poses a constant threat to the lives and security of the population, it is particularly difficult to strike a balance between the requirements of protecting freedom of expression and the imperatives of protecting the democratic State. ${ }^{124}$

Since the collapse of the Soviet Union and accession of almost all of the former Soviet Bloc states in Europe to the Council of Europe, the Court has been faced with an entirely different challenge of transitional democracies in those states. ${ }^{125}$ Nevertheless, the Convention "to which most central and Eastern European countries acceded in the years immediately following the demise of communist regimes, was a crucial signpost on the road to democracy and the rule of law."126 It is worth noting that such challenges were not limited to the former Soviet Bloc states, and the Court had previously faced similar tasks in the case of Southern European states. ${ }^{127}$ Although the process of transition does not prompt the Court to deviate from its established jurisprudence, the Court's judgments on freedom of expression are of particular importance to the transitional process. ${ }^{128}$ Therefore, the Court's case law has strongly adopted an approach in which information exchange and pluralities of opinions are of paramount importance in any democratic society, thereby restoring a balance between the citizens' fundamental rights and the state - a balance completely void in the era of authoritarian rule in the former communist states of Eastern Europe. ${ }^{129}$

123. Antoine Buyse, The truth, the past, and the present: Article 10 ECHR and situations of transition, in Transitional Jurisprudence and the ECHR 131, 132 (Antoine Buyse and Michael Hamilton eds., 2011).

124. Castells v. Spain, App. No. 11798/85, 236 Eur. Comm'n H.R. Dec. \& Rep. (1991) (Carrillo, J., concurring).

125. Peter Leuprecht, Innovations in the European System of Human Rights Protection: Is Enlargement Compatible with Reinforcement?, 8 Transnat'1L. \& Contemp. Probs. 313, 326 (1998). See also Elke Fein, Transitional Justice and Democratization in Eastern Europe, in (Un)Civil Societies 197, 197-223 (Rachel A. May \& Andrew K. Hamilton, eds., 2005).

126. Buyse, supra note 123 , at 148.

127. See generally Philippe C. Schmitter, An Introduction to Southern European Transitions from Authoritarian Rule: Italy, Greece, Portugal, Spain and Turkey, in Transitions from Authoritarian Rule: Southern Europe, (Guillermo O’Donnell, Phillipe C. Schmitter, \& Laurence Whitehead eds., 1986).

128. Buyse, supra note 123, at 148.

129. Id. at 149. 


\subsection{ARTICLE 11: FREEDOM OF ASSEMBLY AND ASSOCIATION}

Freedom of assembly and association provide protection for the formation of collective entities by individuals for any lawful purpose. ${ }^{130}$ Thus, political parties play a special role within the guarantee of freedom of association due to their pivotal role in the functioning of a democratic government. ${ }^{131}$ The Grand Chamber has referred to "the primordial role played in a democratic regime by political parties enjoying the freedoms and rights enshrined in Article 11 and also in Article 10 of the Convention." ${ }^{132}$ Not only citizens in fledgling democracies of Eastern Europe, but also some nationals of the more established democracies in Europe, have had to rely on the Court's jurisprudence in relation to the rights to freedom of assembly and association (Article 11 of Convention) and the obligation upon states to hold free elections (Article 3, of Protocol No. 1 of the Convention). ${ }^{133}$ "Article 11 protects the two distinct, if sometimes connected, freedoms of peaceful assembly and association." ${ }^{134}$ On occasion, states have sought to justify interference with these rights in order to foster democratic values, in turn leading to allegations of excessive rights limitations. ${ }^{135}$

In recent years, the Court has had to deal with the more practical application of the notion of democracy in regards to freedom of assembly and association. ${ }^{136}$

130. Marauhn, T., 'General Principles' in Ehlers, D. \& Becker, U. (eds.), European Fundamental Rights and Freedoms, de Gruyter, 2007, 122.

131. See Council of Europe, European Convention on Human Rights, Nov. 4, 1950, section 1, art. 11 (entered into force Jun. 1, 2010) which states:

"The right to freedom of association as provided in Article 11 of the Convention reads as follows:

1. Everyone has the right to freedom of peaceful assembly and to freedom of association with others, including the right to form and to join trade unions for the protection of his interests.

2. No restrictions shall be placed on the exercise of these rights other than such as are prescribed by law and are necessary in a democratic society in the interests of national security or public safety, for the prevention of disorder or crime, for the protection of health or morals or for the protection of the rights and freedoms of others. This Article shall not prevent the imposition of lawful restrictions on the exercise of these rights by members of the armed forces, of the police or of the administration of the state."

132. Linkov v. Czech Republic, No. 10504/03, \$34, (2006). See Redfearn v. United Kingdom, 2012 Eur. Ct. H.R. 402, 416 (2012).

133. Michael Hamilton, Transition, political loyalties and the order of the state, in Transitional Jurisprudence and the ECHR 151, 151 (Antoine Buyse and Michael Hamilton eds., 2011). See Council of Europe, European Convention on Human Rights, Nov. 4, 1950, art. 1 (entered into force Jun. 1, 2010), which states: "[T] he High Contracting Parties undertake to hold free elections at reasonable intervals by secret ballot, under condition which will ensure the free expression of the opinion of the people in the choice of the legislature.").

134. HARRIS ET AL., supra note 15, at 710.

135. Hamilton, supra note 133, at 152.

136. See United Communist Party of Turkey v. Turkey, App. No. 133/1996/752/951, Eur. Ct. 
The eligibility to stand for election to a national parliament was examined in the case of Zdanoka v. Latvia, which concerned refusal by the Latvian authorities to allow the applicant, Mrs. Tatjana Zdanoko, ${ }^{137}$ a member of the Communist Party of Latvia, to be included on the resident's register to stand for the first parliamentary elections in 1993 since Latvia's regaining independence from the Soviet Union in $1991 .^{138}$

The Chamber and Grand Chamber in this case adopted entirely different approaches to the interpretation of someone's eligibility to stand for election. On the one hand, in its Chamber judgment, the Court held that the electoral restrictions by the Latvian government in 1995 had violated Mrs. Zdanoka's Article 3 of Protocol Iright to free elections. The Chamber felt compelled to "adhere to the same criteria" permitted by Articles 8-11, since "the only type of necessity capable of justifying an interference with any of those rights is, therefore, one which may claim to emanate from democratic society."139 However, the Grand Chamber held:

[W] here an interference with Article 3 of Protocol No. 1 is in issue the Court should not automatically adhere to the same criteria as those applied with regard to the interference permitted by the second paragraphs of Articles 8 to 11 of the Convention .... Because of the relevance of Article 3 of Protocol No. 1 to the institutional order of the State, this provision is cast in very different terms from Articles 8 to 11 of the Convention .... The standards to be applied for establishing compliance with Article 3 of Protocol No. 1 must therefore be considered to be less stringent than those applied under Articles 8 to 11 of the Convention. ${ }^{140}$

Hence, the implied defense to "the institutional order of the state" echoes specific reference to Article 3 of Protocol No. $1{ }^{141}$ By adopting this approach, the Grand Chamber established a high supervisory threshold in which case a violation would only take place if procedural deficiencies gave rise to likely arbitrary treatment. ${ }^{142}$ It is clear that the Grand Chamber was of the opinion that Article 3 of Protocol No. 1 does not exclude the restrictions on electoral rights, since it may be imposed on "an individual who has, for example, seriously abused a public

H.R. (1998), which summarizes the general principle in the case-law in this field.

137. Zdanoka v. Latvia, 2006 Eur. Ct. H.R. at $3 \& 7$ (detailing that in February 1993, Ms. Zdanoka became chairperson of the Movement for Social Justice and Equal Rights in Latvia, (Kustība par sociālo taisnīgumu un līdztiesību Latvijā), which later became a political party, Lìdztiesība ("Equal rights")).

138. Zdanoka, 2006 Eur. Ct. H.R. at 3 \&7. See also Gitonas v. Greece, Eur. Ct. H.R. at 1-19.

139. William A. Schabas, The European Convention on Human Rights: ACommentary, 503 (Oxford Univ. Press, 2015).

140. Zdanoka, 2006 Eur. Ct. H.R. at 36.

141. Hamilton, supra note 133, at 157.

142. Id. See also Zdanoka, 2006 Eur. Ct. H.R. at 33. 
position or whose conduct threatens to undermine the rule of law or democratic foundations." 143

This approach is very much in step with Allen's observation that "there is reluctance to allow the Court to be used as a forum for hearing disputes that have their origin in the pre-transitional era" since "there is a strong (though not universal) belief within the European Court that there is little to be gained by investigating the stories of victim." ${ }^{144}$ In other words, in such cases, the contracting states are given considerable latitude to establish their constitutional rules regarding the status of parliamentarians which inevitably would include the criteria for disqualification. ${ }^{145}$ This would include ensuring the independence of members of parliament, as well as the electorate's freedom of choice. ${ }^{146}$ The wide margin of appreciation given to states is primarily justified on the basis that each state has historical and political factors unique to them and the criteria would vary accordingly. ${ }^{147}$ Nonetheless, according to Hamilton:

One apparent consequence of the more relaxed scrutiny of [Article 3 of Protocol 1] is that no assessment need be made of extant transitional risk. This again sharpens the contrast with [Articles 10 and 11 of Convention] which demand attention to the imminence of an evidenced threat. ${ }^{148}$

However, the Court was unanimous in its decision that Latvia did not violate Article 3 of Protocol 1. ${ }^{149}$ Indeed, this judgment indicates the Court's concern regarding fairness of free elections, as well as enabling states to place limitations on the senior holders of public office to gain electoral advantage whilst still connected with the prestige and powers of such offices. ${ }^{150}$

However, in an apparent U-turn, the Court found violations of Article 3 of Protocol 1 in the case of Adamsons v. Latvia with similar background in 2008. ${ }^{151}$ Some scholars have observed that the above two cases indicate a narrowing of the gap between Article 11 and Article 3 of Protocol 1 scrutiny. ${ }^{152}$ In Adamsons, the Latvian government had disqualified a former low-ranking officer of the KGB border guard from standing in the 2002 general election. In a departure from the previous approach, not only did the Court consider the affiliation of this person's involvement with the previous regime but crucially considered his activities in the

143. Zdanoka, 2006 Eur. Ct. H.R. at 33 (citing Glimmerveen v. the Netherlands (nos. $8348 / 78$ and 8406/78, Commission decision of 11 October 1979, DR 18, 187).

144. Allen, T., "Restitution and Transitional Justice in the European Court of Human Rights," 13(1) Columbia Journal of European Law 1, 30 (2007).

145. Paksas v. Lithuania, 2011 Eur. Ct. H.R. at 26-27.

146. Sarukhanyan v. Armenia, 2008 Eur. Ct. H.R.

147. 38 Zdanoka v Latvia (GC), op. cit., para. 119.

148. Hamilton, supra note 133, at 157.

149. Zdanoka, 2006 Eur. Ct. H.R. at 135.

150. Mowbray, supra note 69, at 708 .

151. Press Release, Registrar, Eur. Ct. H.R., Adamsons v. Latvia (2008). See also Martin Varju, Transition as a Concept of European Human Rights Law, Eur. Hum. Rts. Rev. 170 (2009).

152. Hamilton, supra note 133 , at 181. 

EUROPEAN CONVENTION ON HUMAN RIGHTS

society since the collapse of the Soviet Union which, according to the Court:

The Court considered, in the light of the particular socio-historical background to the applicant's case, that during the first years after Latvia had regained independence electoral rights could be substantially restricted without thereby infringing Article 3 of Protocol No. 1. However, with the passing of time, a mere general suspicion regarding a group of persons no longer sufficed and the authorities had to provide further arguments and evidence to justify the measure in question." 153

This approach has since been reiterated by the Court in the case of Tanase $v$. Moldova, in which the Court held that prevention of a Moldovan citizen holding dual nationality from standing in for election "some seventeen years after Moldova had gained independence and five years after it had relaxed its laws to allow dual-citizenship" was illegal. ${ }^{154}$

\subsubsection{ThE CONVENTION RIGHTS AND POLITICAL PARTIES}

As noted above, political parties are the very cornerstones of European democracy, and the Court considers pluralism as an inseparable part of liberal democracy. In order to maintain political debate, political parties are the other crucial participants of a pluralistic system of government. The Court has opined that:

Such expression is inconceivable without the participation of a plurality of political parties representing the different shades of opinion to be found within a country's population. By relaying this range of opinion, not only within political institutions but also - with the help of media - at all levels of social life, political parties make an irreplaceable contribution to political debate, which is at the very core of a democratic society. ${ }^{155}$

In the case of Socialist Party and Others v. Turkey, the Court emphasised the importance of pluralism in a democratic society to the extent that challenging the existing national structure was acceptable only through democratic means, and that "[i]t is of the essence of democracy to allow diverse political programmes to be proposed and debated, even those that call into question the way a State is currently organised, provided that they do not harm democracy itself." ${ }^{156}$ Hence, constitutional reform, even of a fundamental nature, is a justifiable topic of political debate as long as the advocates are not seeking to undermine the very foundation of the national democratic system. ${ }^{157}$

153. Press Release, supra note 151 , at 3.

154. Tanase v. Moldova, 2010 Eur. Ct. H.R. at 42.

155. United Communist Party of Turkey v. Turkey, Eur. Ct. H.R. at 19 (1998).

156. Socialist Party v. Turkey, Eur. Ct. H.R. at 26 (1998).

157. Contra German Communist Party v. Federal Republic of Germany, App. No. 250/57, 
In the early 1990s, one of the challenges for the Court's jurisprudence was presented with a series of cases involving the banning of nine political parties in Turkey. ${ }^{158}$ In the first eight cases, the Court's approach was very similar in its reasoning. ${ }^{159}$ In each case, these political parties were banned because they were striving to settle the Kurdish problem democratically and advocating a federal state comprised of a Kurdish and a Turkish nation. The Court held that these bans were unjustifiable because, while the states could take measures to protect their institutions, a political party could not be excluded from the protection of the Convention simply because the activities of these political parties are regarded by the national authorities as undermining the constitutional structure of the state. ${ }^{160}$

In the case of United Communist Party of Turkey and Others v. Turkey, the Court held that the mere inclusion of the word "Communist" in the name of a party could not justify dissolution of that party. ${ }^{161}$ In contrast to the case of German Communist Party, the Court in United Communist Party of Turkey reasoned that a party posed no threat to Turkish society because it did not pursue traditional communist aims. ${ }^{162}$ The Court was unanimous in their conclusion regarding the aforementioned parties and that, since they bore no responsibility for Kurdish terrorism, the dissolution violated Article $11 .{ }^{163}$ However, in contrast to abovementioned cases, the seminal exception was the Court's now notorious decision in the case of Refah Partisi (the Welfare Party) v. Turkey, in which the Court upheld the decision of the Turkish Supreme Court to ban an Islamist party. ${ }^{164}$ The coming to prominence by the Refah Partisi in Turkey very much reflected the rise of an "Islamic resurgence" at the end of the twentieth century. ${ }^{165}$ In spite of its secular political system, Turkey, a predominantly Muslim state, was not different from other Islamic countries experiencing this sea change. ${ }^{166}$

Eur. Comm'n H.R. Dec. \& Rep. at 4-5 (1956).

158. Anagnostou et al., The European Court of Human Rights and the Rights of Marginalized Individuals and Minorities in National Context, 176.

159. Emek v. Turkey, App. No. 39434/98,(2005); Democracy and Change Party v. Turkey, App. No. 39210/98 and 39974/98,(2005); Socialist Party of Turkey (STP) v. Turkey, Eur. Ct. H.R. 14 (2003); Dicle on Behalf of the Democracy Party (DEP) v. Turkey, Eur. Ct. H.R. (2002); Yazar v. Turkey, 2002 Eur. Ct. H.R. at 3; Freedom and Democracy Party (ÖZDEP) v. Turkey, Eur. Ct. H.R. at 6 (1999); Socialist Party v. Turkey, Eur. Ct. H.R. at 11 (1998); United Communist Party of Turkey v. Turkey, Eur. Ct. H.R. at 5 (1998).

160. United Communist Party of Turkey and Others v. Turkey, Eur. Ct. H.R. at 15 (1998).

161. Id. at 24 .

162. Id. at 25 .

163. Id. at 58-59.

164. Refah Partisi (The Welfare Party) v. Turkey, 2003 Eur. Ct. H.R at 4-5, 44.

165. John L. Esposito \& O. Voll, Islam and Democracy 202 (1996) describes the rise of Islamic political movements as one of the "great developments" at the end of the twentieth century.

166. Refah Partisi (the Welfare Party) was established in 1983, and soon experienced success in local and general elections. In the Turkish general election in December 1995, Refah Partisi obtained 22 percent of the vote and was the biggest political party in the Grand National assembly. On June 28, 1996, it came to power as the senior partner in a coalition government and in January 
The Court unanimously ruled that there was no violation of Article 11, a decision vehemently criticised by some prominent scholars, such as Dominic McGoldrick. ${ }^{167}$ This was mainly due to the fact that the leaders of Refah had made public speeches advocating for the imposition of Sharia law, which was considered irreconcilable with the notion of liberal democracy, as conceived by the Convention. ${ }^{168}$ As Harvey puts it: "Given that the party had over four million members this amounts to the largest single interference with freedom of association in European jurisprudence."

In Partidul Comunistilor (Nepeceristi) (PCN) and Ungureanu v. Romania, the Court found a violation of Article 11 following the refusal of the Bucharest Court of Appeal to register PCN as a political party. ${ }^{170}$ PCN's political programme aimed at "establishing a humane state based on Communist doctrine, which would imply that the constitutional and legal order in place since 1989 is inhumane and not founded on genuine democracy." ${ }^{\prime 11}$ The Court in Strasbourg rejected the Romanian government's argument that it could not permit "the emergence of a new Communist party to form the subject of democratic debate." ${ }^{172}$ It reiterated the importance of political parties in view of their essential role in ensuring pluralism and the proper function of democracy." 173 And as the Court has said many times "there can be no democracy without pluralism."174 Finally, it was emphasised that:

The Court is also prepared to take into account the historical background to cases before it, in this instance Romania's experience of totalitarian communism prior to 1989 . However, it observes that that context cannot by itself justify the need for the interference, especially as communist parties adhering to Marxist ideology exist in a number of countries that

1997, an opinion poll suggested that it was likely to win 67 per cent of the votes in the following general election to be held four years later. On January 16, 1998, the Constitutional Court of Turkey ordered the dissolution of the party. See generally Carter Vaughn Findley, Turkey, Islam, Nationalism, and Modernity: A History, (2011). See also Erich J. Zurcher, Turkey: A Modern History, (2004).

167. Dominic McGoldrick, Accommodating Muslims in Europe: From Adopting Sharia Law to Religiously Based Opt Outs from Generally Applicable Laws, 9 Hum. Rts. L. Rev. 603, 612-15 (2009).

168. Refah Partisi (The Welfare Party) v. Turkey, 2003 Eur. Ct. H.R.

169. Paul Harvey, Militant Democracy and the European Convention on Human Rights, 29(3) Eur. L. Rev. 407, 417 (2004).

170. Partidul Comunistilor (Nepeceristi) (PCN) v. Romania, App. 46626/99, 3 February 2005.

171. Id. at 10. (Article 20 of the PCN's constitution stated that the PCN was 'not the successor of the former Romanian Communist Party').

172. Id. at 55 .

173. Id. at 44 .

174. Id. at 45 . 
are signatories to the Convention. ${ }^{175}$

The approach of the Court in the above case could be construed as quite a departure from previous case-law regarding former Communist Eastern European states. ${ }^{176}$ Nonetheless, it should be pointed out that PCN had made it absolutely clear that it accepted pluralism, multi-party elections and a political system based on respect for others and their political opinions, and crucially had no affiliation with the former Romanian Communist Party. ${ }^{177}$ On the part of the Court, in the words of Hamilton: "the Court has demonstrated its resolve to foster a robust and inclusive political sphere, underpinned by the values of pluralism and social cohesion." 178

In this regard, the Court in its judgement of the case of Herri Batasuna and Batasuna v. Spain, is unequivocal in stating that a political party may seek a change within the legal and constitutional structure of the state according two criteria: "firstly, the means used to that end must in every respect be legal and democratic; secondly, the change proposed must itself be compatible with fundamental democratic principles." ${ }^{179}$ Therefore, it necessarily follows that:

a political party whose leaders incite to violence or put forward a policy which fails to respect democracy or which is aimed at the destruction of democracy and the flouting of the rights and freedoms recognized in a democracy cannot lay claim to the Convention's protection against penalties imposed on those grounds. ${ }^{180}$

The Court found that the dissolution of political parties which had connections with the Basque terrorist organization ETA, by orders of the domestic courts in Spain, was compatible and lawful under Article 11(2) of the Convention. ${ }^{181}$ This was in the light of the fact that the views and ambitions of the applicant political party, given their links to a terrorist organization, posed a serious threat to Spain and its democracy. ${ }^{182}$

In the recent case of Vona $v$. Hungary, the Court was of the opinion that the dissolution of the Hungarian Guard Association (Magyar Garda) by a domestic court was a lawful restriction of the applicant's rights under Article 11 of the Convention. ${ }^{183}$ The said organization had openly advocated a racist message

175. Id. at 58 .

176. Sveltlana Tyulkina, Militant Democracy: Undemocratic Political Parties AND BEYOND, 93 (Routledge, 2016).

177. Id. at 52. (The Court could see no calls for violence or anti-democratic statements in the Party's proposed constitution). See also Sweeney, The European Court of Human Rights in the Post-Cold War Era: Universality in Transition, 198 (Routledge, 2014).

178. Hamilton, supra note 133, at 181.

179. Herri Batasuna v. Spain, 5 Eur. Ct. H.R. 1, 79 (2009), at 79.

180. Id. at 79 .

181. Id. at 93 .

182. Id. at 94 .

183. Vona v. Hungary, 2 Eur. Ct. H.R. 1, 71 (2013). 

EUROPEAN CONVENTION ON HUMAN RIGHTS

against the Romani population of Hungary. ${ }^{184}$ In the Court's view:

[T] he State is entitled to take preventive measures to protect democracy vis-à-vis such non-party entities as well, if a sufficiently imminent prejudice to the rights of others undermines the fundamental values upon which a democratic society rests and functions. One of such values is the cohabitation of members of society without racial segregation, without which a democratic society is inconceivable. ${ }^{185}$

The Court found that the Hungarian authorities were entitled to take preventive measures in order to protect democracy and proscribe the organization due to its racist and divisive views. ${ }^{186}$ It is noteworthy that the Strasbourg Court through its case law has consistently reiterated that there are positive obligations on governments to secure the effective enjoyment of the rights contained in Article 11(1) of the convention. ${ }^{187}$ The choice of means of implementing these obligations are left to the government concerned, however. ${ }^{188}$ In other words, not only is everyone, regardless of their status or background characteristics (ethnicity, place of origin, religion, disability, etc.), entitled to effective enjoyment of these rights, but the contracting states are under an obligation to prevent and remedy any breach thereof. ${ }^{189}$

\subsection{ARTICLE 17 AND THE COURT'S JURISPRUDENCE}

According to Pierre-Henri Teitgen, the French jurist who was one of the driving forces behind the drafting of the Convention, it truly reflected the general post World War II perception that democracies need to defend themselves against the threat of totalitarianism. ${ }^{190}$ Adoption of Article 17 of the Convention, which prohibits the abuse of rights and prevents totalitarian and extremist groups from justifying their activities by relying on the Convention, encapsulates this approach. ${ }^{191}$ This is exactly what the Court had to do in the early days of its

184. Id. at 10; see also Patrick Thornberry, The International Convention on Elimination of All Forms of Racial Discrimination: A Commentary, 302 (Oxford University Press, 2016).

185. Id. at 57.

186. Id. at 958 .

187. Ouranio Toxo v. Greece, App. No. 74989/01, 20 October 2006, at 37.

188. European Fundamental Rights and Freedoms, at 119 (D. EHLERS, ed., De Gruyter Recht, Berlin 2007).

189. Pieter Van Dijk \& Fried Van Hoof et.al., Theory and Practice of European Convention on Human Rights, 589 (1984).

190. Ed Bates, The Evolution of the European Convention on Human Rights: From Inception to the Creation of a Permanent Court of Human Rights, 44 (Oxford U.P. 2010). (Pierre-Henri Teitgen, delivering a speech before the consultative Assembly of Council of Europe in September 1949).

191. Convention for the Protection of Human Rights and Fundamental Freedoms, Council of 
existence. At this stage it is worth noting that the Court's case law regarding antidemocratic actors since its establishment, until recent decades, was mainly limited to Fascist and Communist applicants. ${ }^{192}$ It is clear that the main idea behind the first proposal for a Convention was to provide human rights guarantees of a very basic and fundamental nature, as a reaction to the atrocities committed in World War II and the subsequent outbreak of the Cold War. ${ }^{193}$ The Court maintains a consistent approach of refusing to consider any applications in relation to Fascist and racist groups from any member states. ${ }^{194}$

Indeed, all such cases have been refused as inadmissible either as manifestly ill-founded or removed from the protection of the Convention on the basis of Article 17, which covers a variety of activities on the far right of the political spectrum, such as distributing racist and fascist propaganda, ${ }^{195}$ denying the Holocaust,${ }^{196}$ organising paramilitary training camps,${ }^{197}$ denying the Austrian state by advocating a Pan-Germanic nation, ${ }^{198}$ and attempting to revive the Fascist party in Italy. ${ }^{199}$

However, the only possible exception to the jurisprudence of the Court in that period was the case of Lehideux and Isorni v. France, ${ }^{200}$ which concerned a criminal conviction on the basis of a newspaper article in praise of Marshall Petain, who headed the collaborationist Vichy regime during the Nazi occupation

Europe, June 1, 2010, Eur. Ct. of H.R. (ARTICLE 17, Prohibition of abuse of rights states: "Nothing in this Convention may be interpreted as implying for any State, group or person any right to engage in any activity or perform any act aimed at the destruction of any of the rights and freedoms set forth herein or at their limitation to a greater extent than is provided for in the Convention.").

192. K.D.P v. Germany, 1 Y.B. Eur. Conv. on H.R. 222 (Eur. Comm'n on H.R.) (In the early decades of the Convention, the European Commission upheld the banning of the German Communist Party by West Germany, thereby extending the reach of Article 17 to allow a member state to enact measures to preclude democracy's capacity to surrender to communist rule.) See also X v. Austria, 26 Eur. Comm'n on H.R. 244 (1982); Piperno v. Italy, App. No. 155510/89, Eur. Comm'n on H.R (1992)).

193. Paul Harvey, Militant Democracy and the European Convention on Human Rights, 29(3) Eur. L. Rev. 3, 413 (2003). See also Luzius Wildhaber, Changing Ideas about the Tasks of the European Court of Human Rights, The European Court of Human Rights 1998-2006: History, Achievements and Reform, 136-138 (Kehl, Strasbourg, Arlington: N.P. Engel 2006); See generally Ed Bates, The Evolution of the European Convention of the European Convention of Human Rights, 1-29 (Oxford U.P. 2010).

194. Jersild v. Denmark, 298 Eur. Ct. of H.R. Ser. A, (1994), at 34.

195. Glimmerveen v. Netherlands, 18 Eur. Ct. of H.R. 187 (1978), at 22.

196. Garaudy v. France, 373 Eur. Ct. of H.R. (2003), at 23.

197. Schimanek v. Austria, Eur. Ct. of H.R. (2000).

198. Association A. and H v. Austria, App. No. 9905/82, 36 Eur. Ct. of H.R 187(Eur. Comm'n on H.R.).

199. X v. Italy, App. No. 6741/74, 5 Eur. Ct. of H.R. 833 (Eur. Comm'n on H.R.).

200. Lehideux and Isorni v. France, 30 Eur. Ct. of H.R. 665 (2000). 

EUROPEAN CONVENTION ON HUMAN RIGHTS

of France. ${ }^{201}$ The Court initially considered the complaint under Article 10 and eventually found that there was a breach of Article 10 due to the disproportionality of applicant's criminal conviction and, as such, unnecessary in a democratic society. ${ }^{202}$ Therefore, by reaching that conclusion, the Court held that it was not appropriate to apply Article $17 .{ }^{203}$ Judge Jambrek, in his concurring opinion, elaborated on conditions in which Article 17 would be applicable:

The aim of the offending actions must be to spread violence or hatred, to resort to illegal or undemocratic methods, to encourage the use of violence, to undermine the nation's democratic and pluralist political system, or to pursue objectives that are racist or likely to destroy the rights and freedom of others. ${ }^{204}$

He was of the opinion that the best way to oppose the rise of anti-Semitism in Europe was "free critique" in which democracies, unlike dictatorships, can cope with the sharpest controversies. ${ }^{205}$ In relation to the applicability of Article 17, Judge Jambrek noted that "on the other hand, the requirements of Article 17 also reflect concern for the defence of democratic society and its institution." ${ }^{206}$ In contrast, the Court has adopted a much more ambivalent attitude towards political movements on the left side of the political spectrum. ${ }^{207}$ Although the Court, after the end of the Cold War, adopted a more tolerant and measured approach towards left-wing political movements. ${ }^{208}$

\section{CONCLUSION}

The concept of a "democratic society" encompasses the entire framework of the Convention and serves as a criterion for the assessment of legality of state action. The Convention entails a broad protection of the substantive rights that are said to be easily identified. As it has been observed, the Court has derived its concept of democracy from the components of the contemporary model of democracy in Europe from its origin, preamble, and text of the Convention. Indeed, the drafters of the European Convention on Human Rights adopted the notions of liberal democracy and pluralism as the very cornerstones of the Convention. In that regard, the Court considers liberal democracy as the only guarantee for fundamental freedom and human rights. The cases that this Article

201. Id. at 47 .

202. Id. at 58 .

203. Id. at 58 .

204. Id. at 2, concurring opinion of Judge Jambrek.

205. Id. at 2 .

206. Id. at 3 .

207. The Communist Party (KPD) v. Germany,1957 1 Y.B. Eur. Conv. on H.R. 222, (Eur. Comm'n on H.R.).; See also Glasenapp v Germany, App. No. 104, 9 Eur. H.R. Rep. 25 (1986).; See also Kosiek v. Germany, App. No. 9704/82, (need which court it was heard before) (1986).

208. Vogt v. Germany, App. No. 17851/91, 21 Eur. H.R. Rep. 205, 28-31 (1995). 
has analysed certainly reveal the Court's adherence to representative democracy and free elections, as well as the importance of transparency and accountability in public and political spheres. Along with reference to a "democratic society" in relation to the qualification of rights, the substantive contents of Articles 10 and 11 of the Convention, and Article 3, Protocol 1 provide a democratic backbone to the Convention system. These are the rights to free expression, free assembly and association, and the right to free elections.

In recent decades, the Court has recognized Article 9 of the Convention as "one of the foundations of a democratic society within the meaning of the Convention." ${ }^{209}$ However, the abovementioned rights are not absolute and are subject to limitations set out in the second part of these articles. The restrictions must be prescribed by law and be necessary in a democratic society in the interest of public safety, for the protection of public order, health, morals, or for the respect of the rights and freedoms of others. Furthermore, the doctrine of "margin of appreciation" allows the member states certain discretion to interfere with or limit human rights in specific instances. This "margin of appreciation," however, is increasingly subject to oversight by the Court in order to ensure objective compliance with the protected rights. This approach is increasingly adopted by the Court in cases concerning transitional democracies in former Communist totalitarian systems.

This article has shown that since the collapse of the Soviet Union, and accession of almost all of the former European communist states to the Council of Europe, the Court has faced a huge challenge in upholding and enforcing the values of democracy, particularly because most of these states were new to the notion of liberal democracy. This led to the emergence of a new kind of applicant bringing litigation against new states defending those cases. This new challenge has prompted the Court to reiterate and articulate a coherent normative conception of democracy, even though that conception is bound to be contested. As a result, democracy in the context of the Convention cannot be understood merely in a formal sense as majority rule. Democracy must primarily be understood as participatory democracy, with respect for different opinions and beliefs, and focused on the freedom of expression as a means of ensuring active involvement of the people in the decision-making processes. 